DOI: 10.1515/adms-2016-0013

${ }^{1}$ Koszalin University of Technology, Faculty of Mechanical Engineering, Department of Engineering and Informatics Systems, Division of Bioengineering and Surface Electrochemistry, Racławicka 15-17, 75-620 Koszalin, Poland

${ }^{2}$ Hochschule Wismar-University of Applied Sciences Technology, Business and Design, Faculty of Engineering, DE 23966 Wismar, Germany

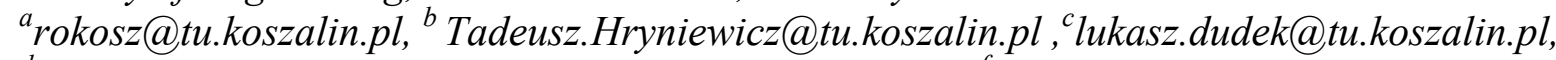
dantje.schuetz@hs-wismar.de, ${ }^{e}$ jan.heeg@hs-wismar.de, ${ }^{f}$ marion.wienecke@hs-wismar.de

\title{
ENERGY-DISPERSIVE X-RAY SPECTROSCOPY MAPPING OF POROUS COATINGS OBTAINED ON TITANIUM BY PLASMA ELECTROLYTIC OXIDATION IN A SOLUTION CONTAINING CONCENTRATED PHOSPHORIC ACID WITH COPPER NITRATE
}

\begin{abstract}
The SEM and EDS study results of coatings obtained on titanium by Plasma Electrolytic Oxidation (PEO) in the electrolytes containing of $600 \mathrm{~g}$ copper nitrate in 1 liter of concentrated phosphoric acid at $450 \mathrm{~V}$ for 1 and 3 minutes, are presented. The obtained coatings are porous and consist mainly of phosphorus within titanium and copper. It was found that the time of PEO oxidation has impact on the chemical composition of the coatings. The longer time of PEO treatment, the higher amount of copper inside coating. The PEO oxidation of titanium for 1 minute has resulted in the creation of coating, on which 3 phases where found, which contained up to $13.4 \mathrm{wt} \%$ ( 9 at $\%$ ) of copper inside the phosphate structure. In case of 1 minute PEO treatment of titanium, the 2 phases were found, which contained up to $13 \mathrm{wt} \%$ ( 8 at $\%$ ) of copper inside the phosphate structure. The copper-tophosphorus ratios after 1 minute processing belong to the range from 0.28 by wt $\%$ ( 0.14 by at $\%)$ to 0.47 by wt $\%$ ( 0.23 by at $\%$ ), while after 3 minutes the same ratios belong to the range from 0.27 by wt $\%$ ( 0.13 by at $\%$ ) to 0.35 by wt $\%(0.17$ by at $\%)$. In summary, it should be stated that the higher amounts of phosphorus and copper were recorded on titanium after PEO oxidation for 3 minutes than these after 1 minute.
\end{abstract}

Key words: Plasma Electrolytic Oxidation (PEO); Micro Arc Oxidation (MAO); SEM; Titanium, $\mathrm{H}_{3} \mathrm{PO}_{4}$, $\mathrm{Cu}\left(\mathrm{NO}_{3}\right)_{2}$

\section{INTRODUCTION}

By using Electropolishing (EP) [1-5], high-current density electropolishing (HDEP) [6-7] as well as magnetoelectropolishing (MEP) [8-15] it is possible to form nano-coatings with different properties than matrix. To obtain porous miro-coatings within micro- and nano- 
pores, the Plasma Electrolytic Oxidation (PEO), known also as Micro Arc Oxidation (MAO), [16-30] should be used. That method of forming the coatings by PEO is now widely used by industry such as Keronite (UK), Magoxide-Coat (Germany) and Microplasmic (USA) [16]; moreover, there are still ongoing research on the development of these coatings manufacturing. The first use of PEO treatment was applied for aluminum [16-22] and its alloys [23-27] oxidization. Afterwards, magnesium and its alloys [26-33] were treated by PEO. Now most important part of titanium, niobium, tantalum, zirconium and their alloys [34-47] is finished with the use of the PEO oxidation. In case of biomaterials, most important is to fabricate the porous surface enriched in antibacterial elements such as silver and/or copper [47-55] without or with the least amount of toxic elements to the human body, such as vanadium, aluminum, and nickel [56-60].

In the present paper, the Authors display the analysis of the porous surfaces obtained on titanium after PEO processing in two electrolytes containing concentrated (85\%) phosphoric acid and copper nitrate by Energy-dispersive X-ray Spectroscopy Mapping.

\section{METHOD AND EXPERIMENTAL SET UP}

The Plasma Electrolytic Oxidation (PEO), known also as Micro arc Oxidation (MOA), was used to perform experiments on a set-up built in the cooperation with the Division of Applied Electronics and Electro-technology, Koszalin University of Technology (KUT), that was in detail described in [42]. The PEO process was performed with the use of a constant voltage of $450 \mathrm{~V}$. The electrolyte consisted of a concentrated $85 \%$ pure p.a. $\mathrm{H}_{3} \mathrm{PO}_{4}(98 \mathrm{~g} / \mathrm{mole})$ acid, one liter, within $600 \mathrm{~g}$ of $\mathrm{Cu}\left(\mathrm{NO}_{3}\right)_{2}$ for two oxidation times, i.e. 1 and 3 minutes, consecutively. The pure titanium (CP Grade 2) samples of dimensions $15 \times 20 \times 1 \mathrm{~mm}$, were prepared at the Faculty of Mechanical Engineering, KUT.

The surface morphology and chemical composition of the samples were investigated by SEM/EDS. EDS measurements have been performed to estimate the relative copper content. An EDAX Octane plus EDS spectrometer with a $30 \mathrm{~mm}^{2}$ detector crystal was used combined with a Zeiss Auriga compact SEM. The EDS spectra and the secondary electron micrographs were recorded at a primary energy of $20 \mathrm{keV}$.

\section{RESULTS}

In Figures 1-4, the SEM images with EDS analyses of titanium after the PEO treatment at $450 \mathrm{~V}$ for 1 minute, in the electrolyte consisting of $600 \mathrm{~g} \mathrm{Cu}\left(\mathrm{NO}_{3}\right)_{2}$ in $1 \mathrm{~L} \mathrm{H}_{3} \mathrm{PO}_{4}$, are shown. The obtained surface is porous and consists of phosphorus, and titanium within copper. Figure 1 shows SEM image and corresponding EDS mapping with three phases. In all phases dominating elements are titanium and phosphorus. The first phase, which is marked in green in Figure 1, contains $18.8 \mathrm{wt} \%$ (7.4 at \%) of copper, which is similar to the amount of copper in the third phase, marked in blue, what is presented in Table 1. The maximum of copper on that surface was recorded in case of the phase marked in red, i.e. $13.4 \mathrm{wt} \%(9 \mathrm{at} \%)$. Additionally, it is important to note that in case of medical use of surfaces after PEO oxidation, it is expected getting high amounts of phosphorus and copper in surface that is to be in contact with tissue, what is observed on the whole surface. The copper-to-phosphorus ratios 
were found, which are equal to 0.28 by wt $\%$ ( 0.14 by at $\%), 0.47$ by wt $\%(0.23$ by at $\%)$ and 0.32 by wt $\%$ ( 0.16 by at $\%)$, for green, red, and blue phases, respectively.

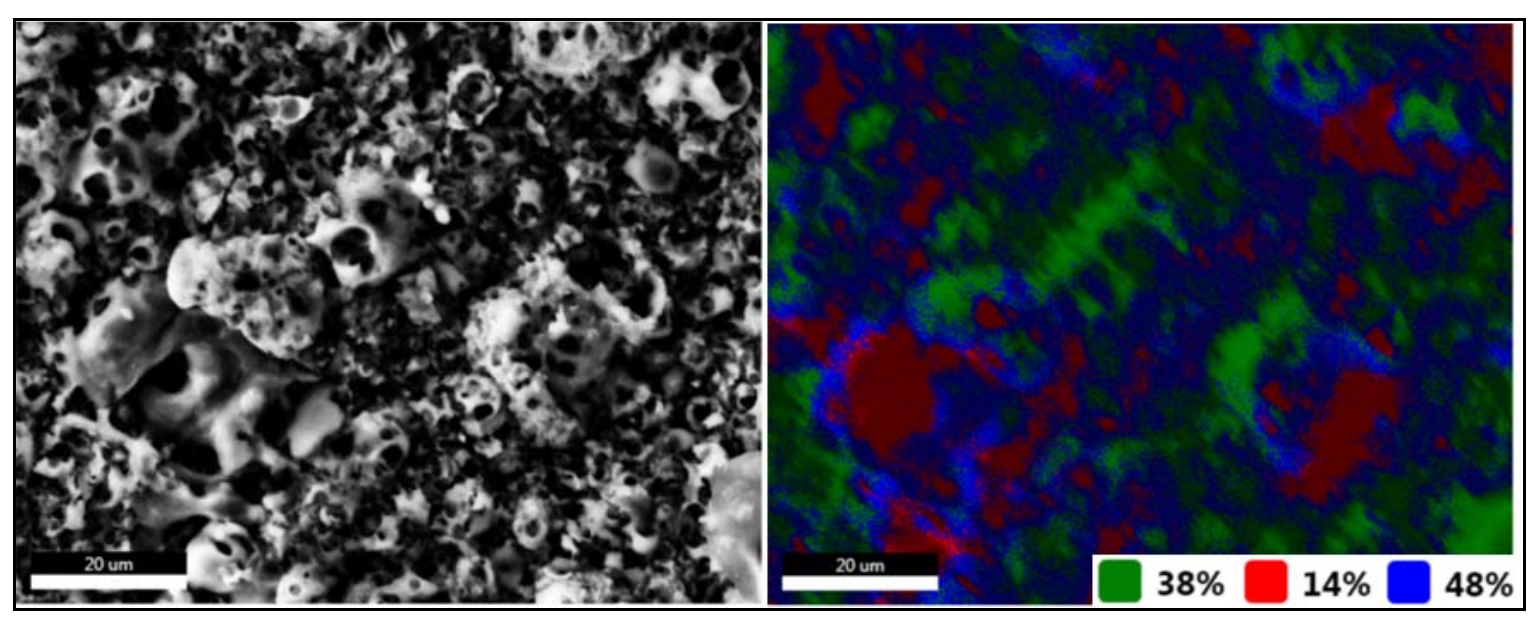

Fig. 1. SEM image (on the left side) and EDS maps (on the right side) of Titanium after PEO treatment at $450 \mathrm{~V}$ for 1 minute in the electrolyte consisting of $600 \mathrm{~g} \mathrm{Cu}\left(\mathrm{NO}_{3}\right)_{2}$ in $1 \mathrm{~L} \mathrm{H}_{3} \mathrm{PO}_{4}$

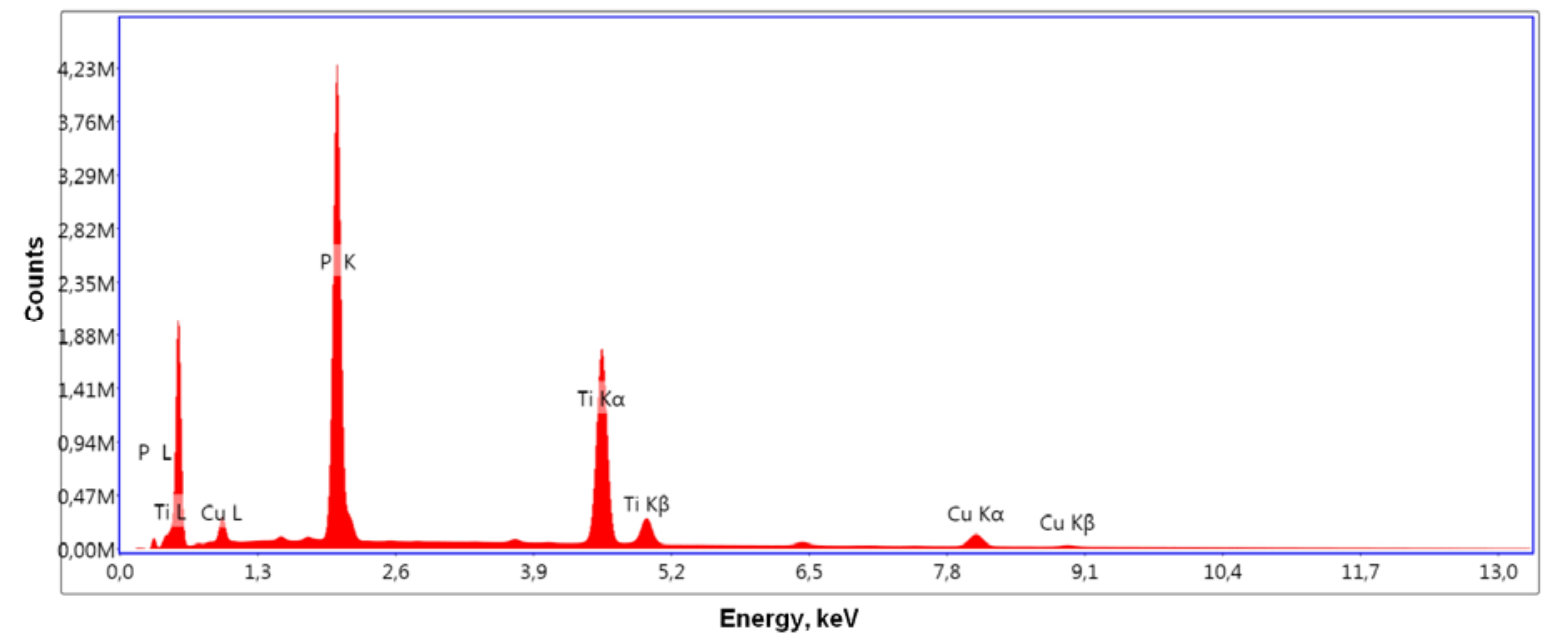

Fig. 2. EDS spectrum of PK/TiK phase (green phase in Fig. 1) of Titanium after PEO treatment at $450 \mathrm{~V}$ for 1 minute in the electrolyte consisting of $600 \mathrm{~g} \mathrm{Cu}\left(\mathrm{NO}_{3}\right)_{2}$ in $1 \mathrm{~L} \mathrm{H}_{3} \mathrm{PO}_{4}$

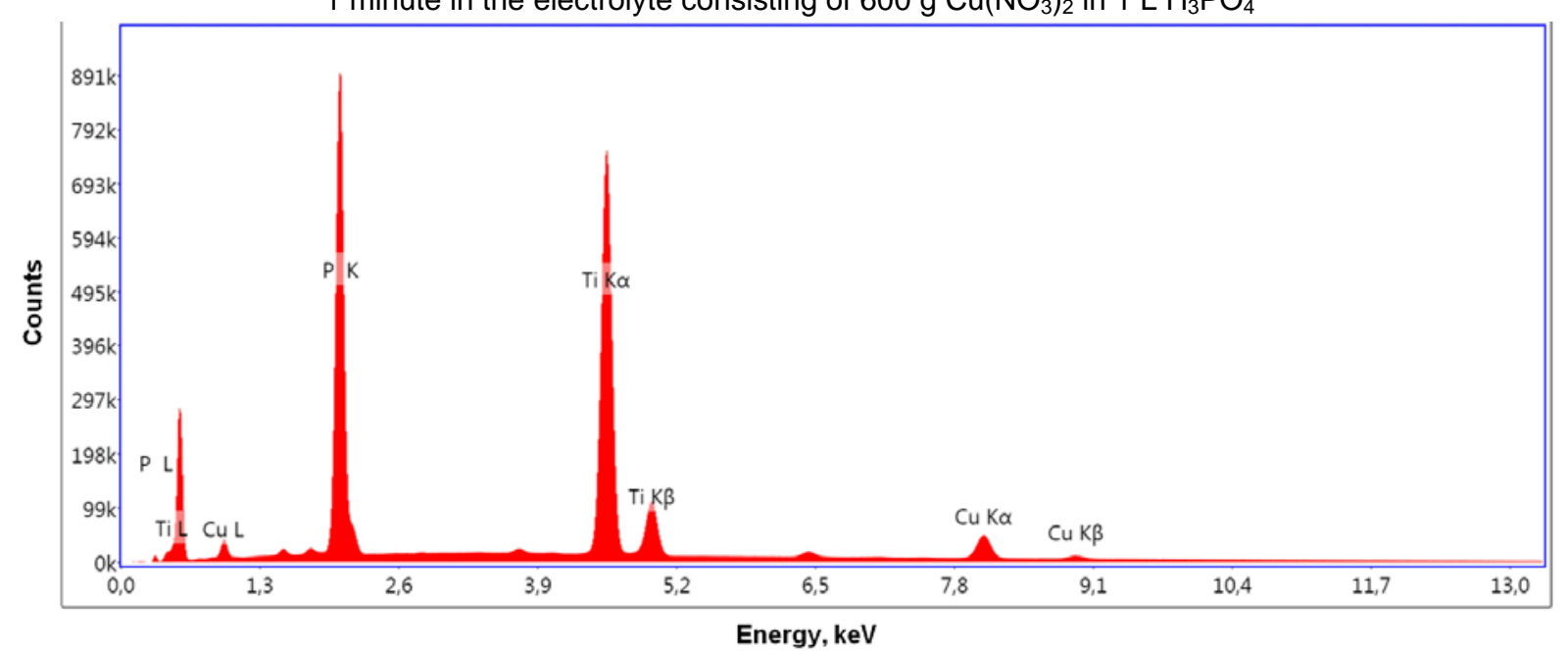

Fig. 3. EDS spectrum of TiK/PK/CuK phase (red phase in Fig. 1) of Titanium after PEO treatment at $450 \mathrm{~V}$ for 1 minute in the electrolyte consisting of $600 \mathrm{~g} \mathrm{Cu}\left(\mathrm{NO}_{3}\right)_{2}$ in $1 \mathrm{~L} \mathrm{H}_{3} \mathrm{PO}_{4}$ 


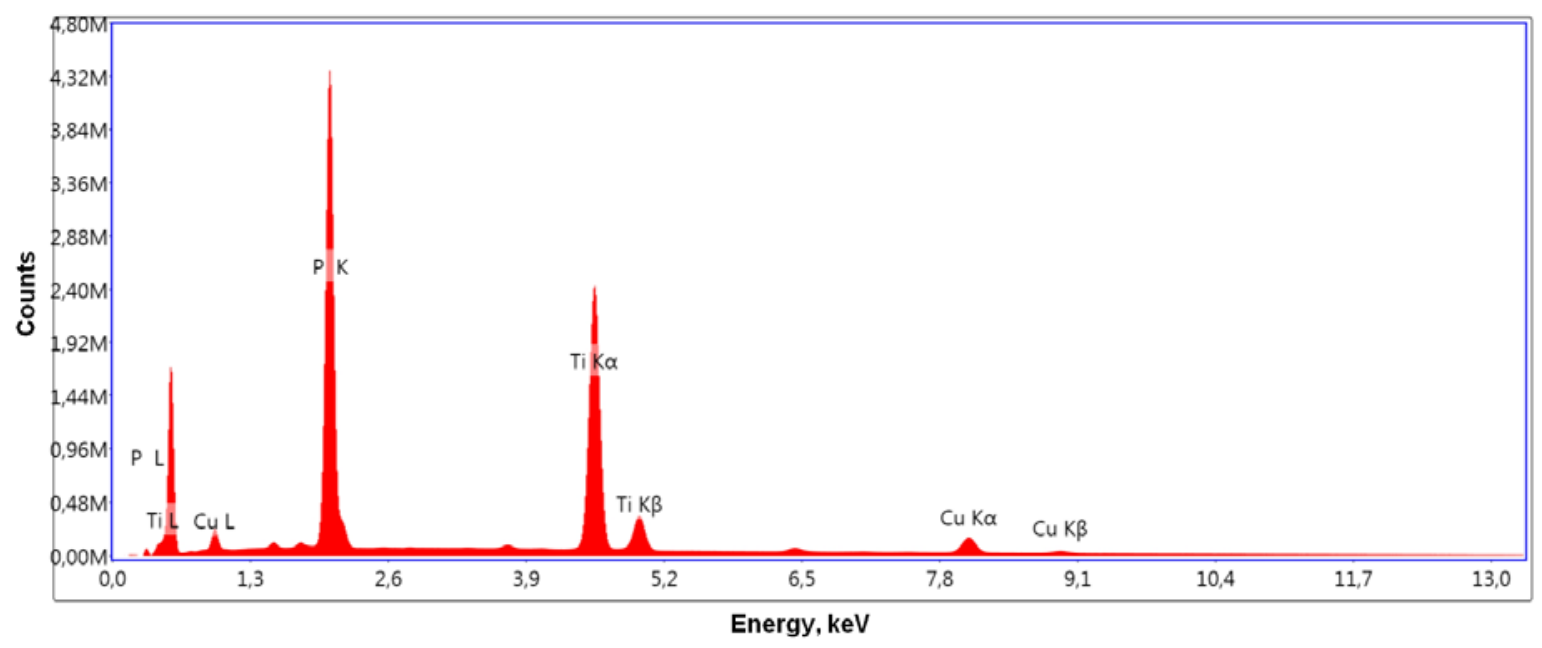

Fig. 4. EDS spectrum of TiK/PK/CuK phase (blue phase in Fig. 1) of Titanium after PEO treatment at $450 \mathrm{~V}$ for 1 minute in the electrolyte consisting of $600 \mathrm{~g} \mathrm{Cu}\left(\mathrm{NO}_{3}\right)_{2}$ in $1 \mathrm{~L} \mathrm{H}_{3} \mathrm{PO}_{4}$

Table 1. Analysis of EDS spectra of Titanium after PEO treatment at $450 \mathrm{~V}$ for 1 minute in the electrolyte consisting of $600 \mathrm{~g} \mathrm{Cu}\left(\mathrm{NO}_{3}\right)_{2}$ in $1 \mathrm{~L} \mathrm{H}_{3} \mathrm{PO}_{4}$

\begin{tabular}{|c|c|c|c|c|c|c|}
\cline { 2 - 7 } \multicolumn{1}{c|}{} & \multicolumn{2}{c|}{ Green phase in Fig. 1 } & \multicolumn{2}{c|}{ Red phase in Fig. 1 } & \multicolumn{2}{c|}{ Blue phase in Fig. 1 } \\
\cline { 2 - 7 } \multicolumn{1}{c|}{} & wt\% & at\% & wt\% & at\% & wt\% & at\% \\
\hline PK & 42.0 & 54.1 & 28.5 & 39.3 & 36.4 & 48.1 \\
\hline TiK & 46.2 & 38.5 & 58.1 & 51.7 & 52.0 & 44.4 \\
\hline CuK & 11.8 & 7.4 & 13.4 & 9.0 & 11.6 & 7.5 \\
\hline
\end{tabular}

In Figures 5-9, the SEM images with EDS analyses of titanium after the PEO treatment at $450 \mathrm{~V}$ for 3 minutes, in the electrolyte consisting of $600 \mathrm{~g} \mathrm{Cu}\left(\mathrm{NO}_{3}\right)_{2}$ in $1 \mathrm{~L} \mathrm{H}_{3} \mathrm{PO}_{4}$, are presented. After that PEO treatment, two phases were found, what is visible in Figure 5. The both phases, i.e. blue and red, consist of similar amounts of copper (12-13 wt $\% \mid 8-8.3$ at $\%$ ), while the amount of phosphorus is higher in case of phase marked in blue, what is shown in Table 2. In order to compare the two phases, the copper-to-phosphorus ratios were found, which for the blue phase is equal to 0.27 by $w t \%(0.13$ by at $\%)$, and for the red one, 0.35 by wt $\%$ $(0.17$ by at $\%)$.

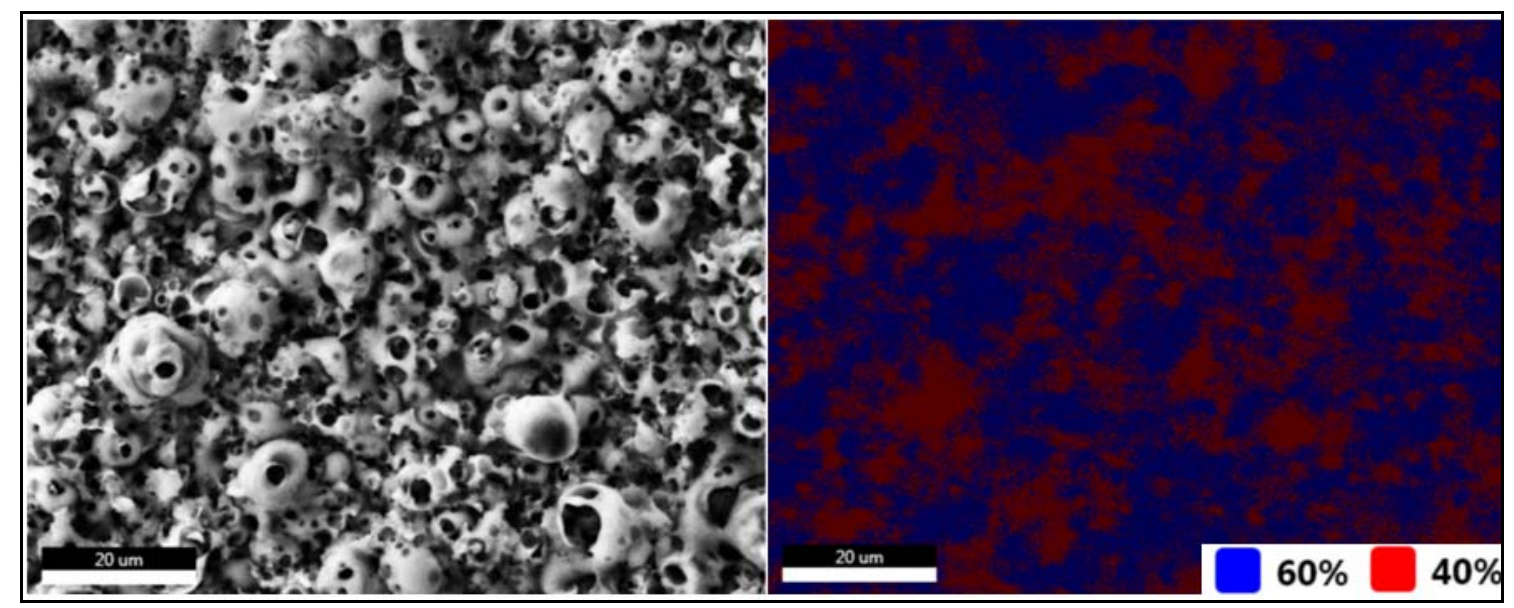

Fig. 5. SEM image (on the left side) and EDS maps (on the right side) of Titanium after PEO treatment at $450 \mathrm{~V}$ for 3 minutes in the electrolyte consisting of $600 \mathrm{~g} \mathrm{Cu}\left(\mathrm{NO}_{3}\right)_{2}$ in $1 \mathrm{~L} \mathrm{H}_{3} \mathrm{PO}_{4}$ 


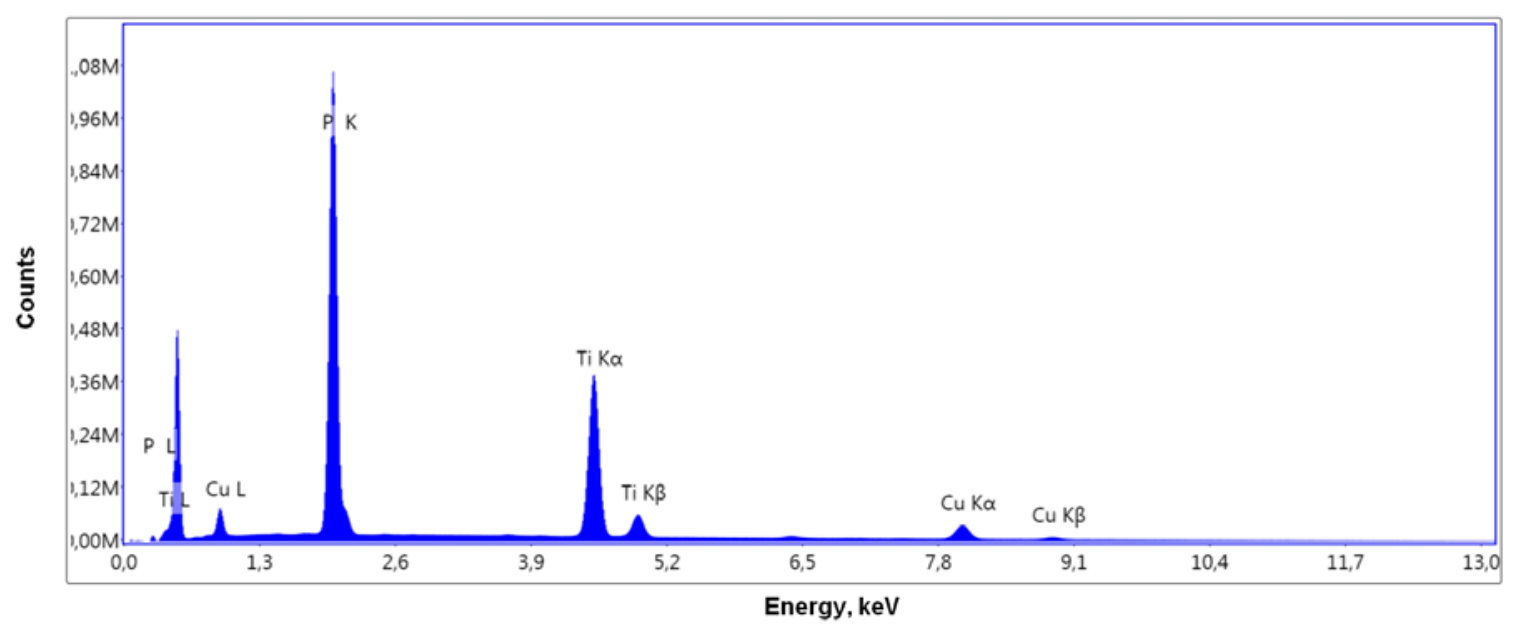

Fig. 6. EDS spectrum of PK/TiK phase (blue phase in Fig. 5) of Titanium after PEO treatment at $450 \mathrm{~V}$ for 3 minutes in the electrolyte consisting of $600 \mathrm{~g} \mathrm{Cu}\left(\mathrm{NO}_{3}\right)_{2}$ in $1 \mathrm{~L} \mathrm{H}_{3} \mathrm{PO}_{4}$

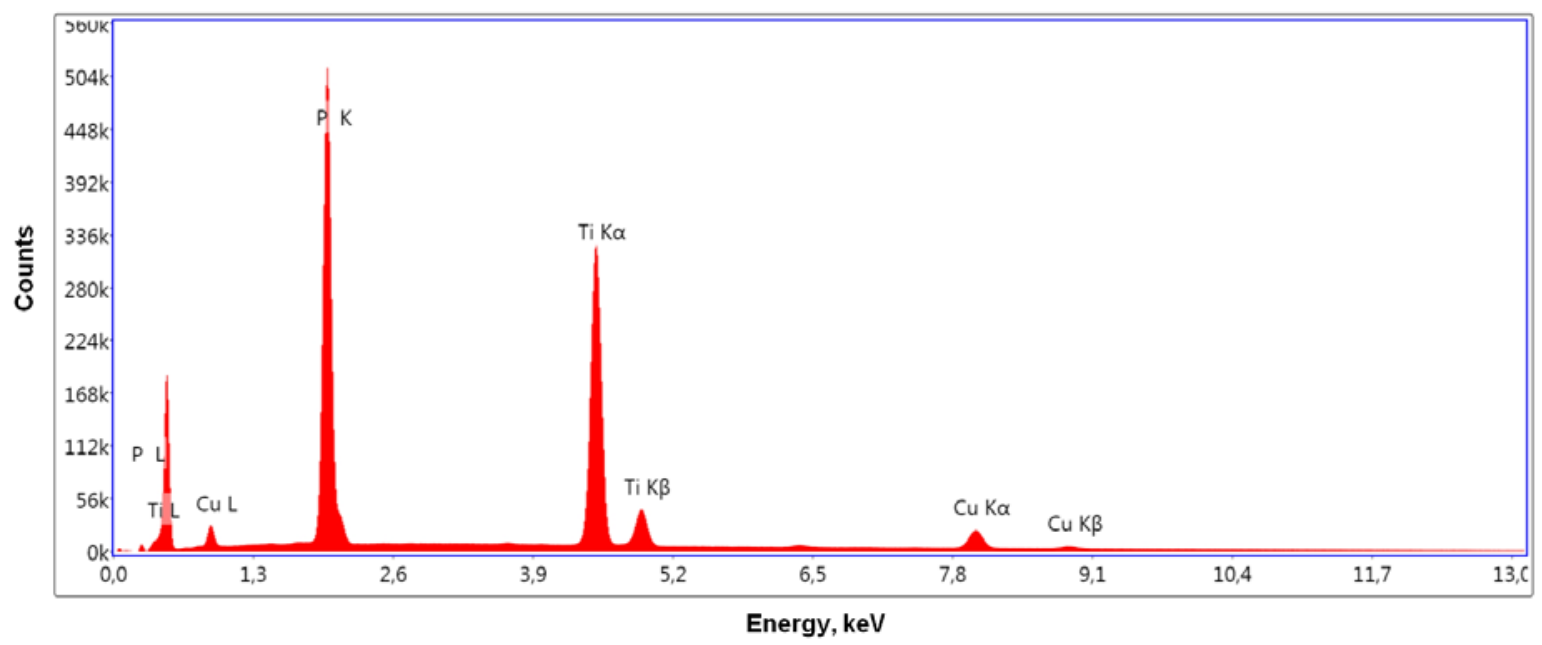

Fig. 7. EDS spectrum of Ti/PK phase (red phase in Fig. 5) of Titanium after PEO treatment at $450 \mathrm{~V}$ for 3 minutes in the electrolyte consisting of $600 \mathrm{~g} \mathrm{Cu}\left(\mathrm{NO}_{3}\right)_{2}$ in $1 \mathrm{~L} \mathrm{H}_{3} \mathrm{PO}_{4}$

Table 2. Analysis of EDS spectra of Titanium after PEO treatment at $450 \mathrm{~V}$ for 3 minute in the electrolyte consisting of $600 \mathrm{~g} \mathrm{Cu}\left(\mathrm{NO}_{3}\right)_{2}$ in $1 \mathrm{~L} \mathrm{H}_{3} \mathrm{PO}_{4}$

\begin{tabular}{|c|c|c|c|c|}
\cline { 2 - 5 } \multicolumn{1}{c|}{} & \multicolumn{2}{c|}{ Blue phase in Fig. 5) } & \multicolumn{2}{c|}{ Red phase in Fig. 5 } \\
\hline & wt\% & at\% & wt\% & at\% \\
\hline PK & 47.9 & 60.2 & 37.0 & 48.8 \\
\hline TiK & 39.1 & 31.8 & 50.2 & 42.9 \\
\hline CuK & 13.0 & 8.0 & 12.8 & 8.3 \\
\hline
\end{tabular}

In Figures 8-9 and in Table 3, the EDS summary spectra of Titanium after PEO treatment at $450 \mathrm{~V}$ for 1 and 3 minutes in the electrolyte consisting of $600 \mathrm{~g} \mathrm{Cu}\left(\mathrm{NO}_{3}\right)_{2}$ in $1 \mathrm{~L} \mathrm{H}_{3} \mathrm{PO}_{4}$, are presented. One may notice that on whole surface the higher amounts of phosphorus and copper are visible on titanium surface after PEO oxidation for 3 minutes. However, it must be pointed out that the final usefulness of the obtained surfaces will be possible after performing the biological researches planned. 


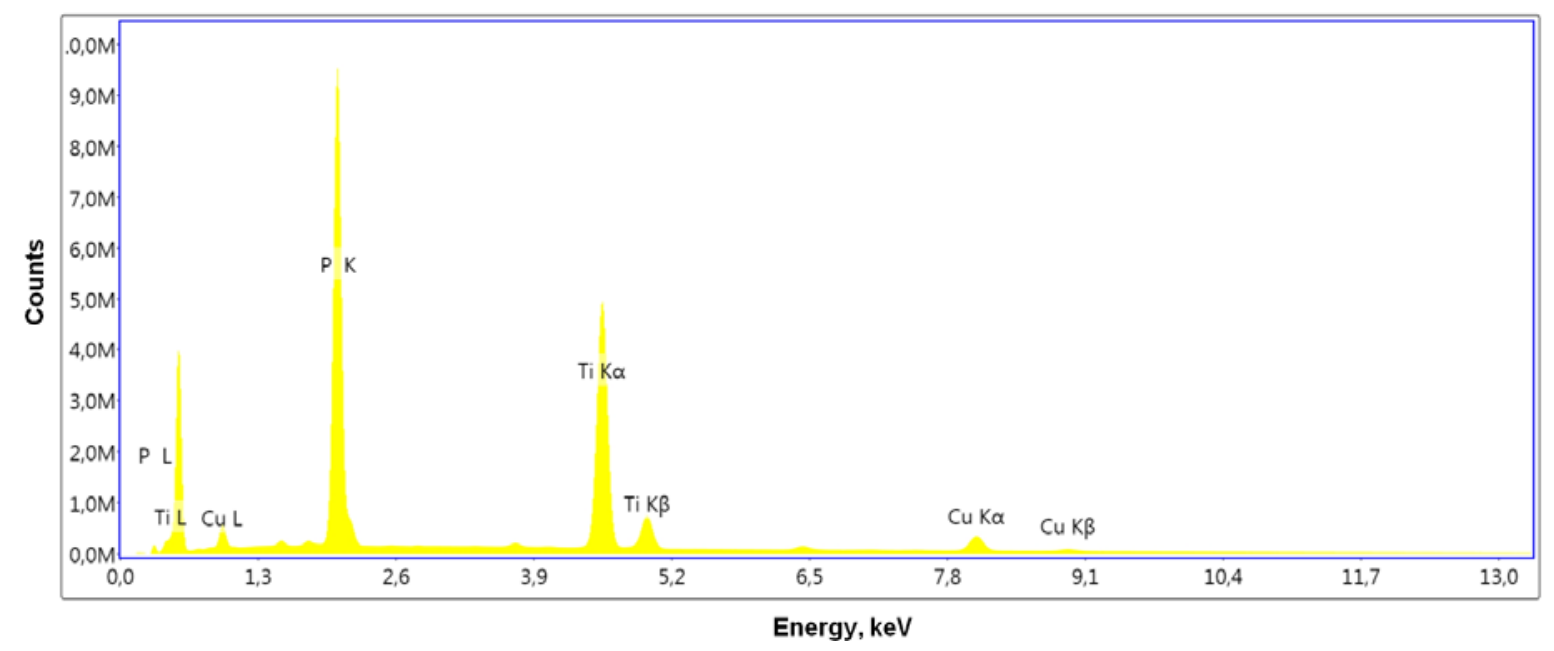

Fig. 8. EDS summary spectrum of Titanium after PEO treatment at $450 \mathrm{~V}$ for 1 minute in the electrolyte consisting of $600 \mathrm{~g} \mathrm{Cu}\left(\mathrm{NO}_{3}\right)_{2}$ in $1 \mathrm{~L} \mathrm{H}_{3} \mathrm{PO}_{4}$

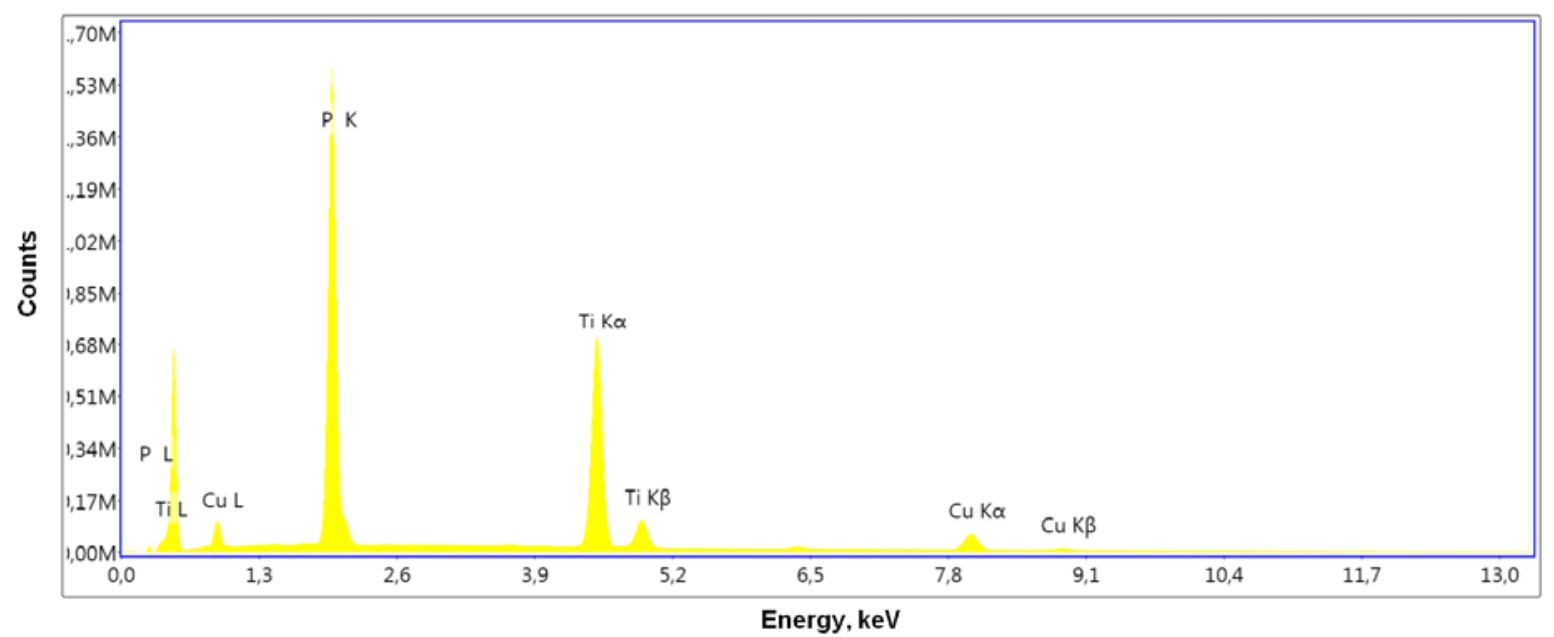

Fig. 9. EDS summary spectrum of Titanium after PEO treatment at $450 \mathrm{~V}$ for 3 minutes in the electrolyte consisting of $600 \mathrm{~g} \mathrm{Cu}\left(\mathrm{NO}_{3}\right)_{2}$ in $1 \mathrm{~L} \mathrm{H}_{3} \mathrm{PO}_{4}$

Table 3. Analysis of EDS summary spectra of Titanium after PEO treatment at $450 \mathrm{~V}$ for $1 \mathrm{~min}$ and $3 \mathrm{~min}$ in the electrolyte consisting of $600 \mathrm{~g} \mathrm{Cu}\left(\mathrm{NO}_{3}\right)_{2}$ in $1 \mathrm{~L} \mathrm{H}_{3} \mathrm{PO}_{4}$

\begin{tabular}{|c|c|c|c|c|}
\cline { 2 - 5 } \multicolumn{1}{c|}{} & \multicolumn{2}{c|}{$\begin{array}{c}\text { PEO at } 450 \mathrm{~V} \\
1 \mathrm{~min}\end{array}$} & \multicolumn{2}{c|}{ PEO at $450 \mathrm{~V}$} \\
\cline { 2 - 5 } \multicolumn{1}{c|}{} & wt\% $\%$ & at\% & wt\% & at\% \\
\cline { 2 - 5 } \multicolumn{1}{c|}{} & 38.3 & 50.1 & 44.3 & 56.6 \\
\hline PK & 50.3 & 42.6 & 43.4 & 35.8 \\
\hline TiK & 11.4 & 7.3 & 12.3 & 7.6 \\
\hline CuK & &
\end{tabular}




\section{CONCLUSIONS}

The following conclusions may be formulated after the PEO treatment processing in the electrolytes containing $600 \mathrm{~g}$ copper nitrate in one liter of concentrated phosphoric acid for two treatment times, i.e. 1 and 3 minutes:

Porous coatings on titanium surface, enriched in copper distributed in the whole volume, were obtained.

1. The time of PEO oxidation has impact on the chemical composition of the coatings.

2. The longer time of PEO treatment, the higher amount of copper inside coating was found.

3. After 1 minute of PEO oxidation of titanium, the 3 phases were found, which contained up to $13.4 \mathrm{wt} \%$ ( 9 at $\%)$ of copper inside the phosphate structure.

4. After 3 minutes of PEO oxidation of titanium, the 2 phases were found, which contained up to $13 \mathrm{wt} \%$ ( 8 at $\%$ ) of copper inside the phosphate structure.

5. After 1 minute of $\mathrm{PEO}$ oxidation of titanium, copper-to-phosphorus ratios belong to the range from 0.28 by wt $\%$ ( 0.14 by at $\%)$ to 0.47 by wt $\%(0.23$ by at $\%)$.

6. After 3 minutes of PEO oxidation of titanium, copper-to-phosphorus ratios belong to the range from 0.27 by wt $\%(0.13$ by at $\%)$ to 0.35 by wt $\%(0.17$ by at $\%)$.

7. The higher amounts of phosphorus and copper were recorded on titanium after the PEO oxidation for 3 minutes.

\section{REFERENCES}

1. Hryniewicz T., Physico-chemical and technological fundamentals of electropolishing steels (Fizykochemiczne i technologiczne podstawy procesu elektropolerowania stali), 1989, Monograph no. 26, ed. by Koszalin University of Technology Publishing.

2. Hryniewicz T., On the surface treatment of metallic biomaterials (Wstęp do obróbki powierzchniowej biomateriałów metalowych), 2007, ed. by Koszalin University of Technology Publishing.

3. Rokosz K., Electrochemical Polishing in the magnetic field (Polerowanie elektrochemiczne w polu magnetycznym), 2012, ed. by Koszalin University of Technology Publishing.

4. Hryniewicz T., Rokicki R., Rokosz K., Co-Cr alloy corrosion behaviour after electropolishing and "magnetoelectropolishing" treatments, Surface and Coatings Technology, 62(17-18) (2008), 3073-3076.

5. Hryniewicz T., Rokosz K., Analysis of XPS results of AISI 316L SS electropolished and magnetoelectropolished at varying conditions, Surface and Coatings Technology, 204(16-17) (2010), 2583-2592.

6. Rokosz K., Hryniewicz T., Simon F., Rzadkiewicz S., Comparative XPS analysis of passive layers composition formed on AISI 304L SS after standard and high-current density electropolishing, Surface and Interface Analysis, 47(1) (2015), 87-92.

7. Rokosz K., Lahtinen J., Hryniewicz T., Rzadkiewicz S., XPS depth profiling analysis of passive surface layers formed on austenitic AISI 304L and AISI 316L SS after high-current-density electropolishing, Surface and Coatings Technology, 276 (2015), 516-520. 
8. Hryniewicz T., Rokicki R., Rokosz K., Magnetoelectropolishing for metal surface modification. Transactions of The Institute of Metal Finishing, 85(6) (2007), 325-332.

9. Hryniewicz T., Rokicki R., Rokosz K., Corrosion and surface characterization of titanium biomaterial after magnetoelectropolishing, Surface and Coatings Technology, 203(9) (2008),15081515.

10. Hryniewicz T.,Rokosz K., Polarization characteristics of magnetoelectropolishing stainless steels, Materials Chemistry and Physics, 122(1) (2010),169-174.

11. Rokosz K., Hryniewicz T., Raaen S., Characterization of passive film formed on AISI 316L stainless steel after magnetoelectropolishing in a broad range of polarization parameters, Journal of Iron and Steel Research, 83(9) (2012), 910-918.

12. Hryniewicz T., Rokosz K., Investigation of selected surface properties of AISI 316L SS after magnetoelectropolishing, Materials Chemistry and Physics, 123(1) (2010), 47-55.

13. Hryniewicz T., Rokosz K., Corrosion resistance of magnetoelectropolished AISI 316L SS biomaterial, Anti-Corrosion Methods and Materials, 61(2) (2014), 57-64.

14. Hryniewicz T., Rokosz K., Valiček J., Rokicki R., Effect of magnetoelectropolishing on nanohardness and Young's modulus of titanium biomaterial, Materials Letters, 83 (2012), 69-72.

15. Hryniewicz T., Rokosz K., Rokicki R., Prima F., Nanoindentation and XPS Studies of Titanium TNZ Alloy after Electrochemical Polishing in a Magnetic Field, Materials, 8 (2015), 205-215.

16. Dehnavi V., Surface Modification of Aluminum Alloys by Plasma Electrolytic Oxidation, University of Western Ontario-Electronic Thesis and Dissertation Repository, paper 2311 (2014), 216 pages.

17. Klapkiv M.D., Nykyforchyn H.M., Posuvailo V.M., Spectral Analysis of an Electrolytic Plasma in the Process of Synthesis of Aluminium Oxide, Materials Science, 30 (1994), 333-343.

18. Yerokhin A.L., Nie X., Leyland A., Matthews A., Dowey S.J., Plasma electrolysis for surface engineering, Surface and Coatings Technology, 122(2-3) (1999), 73-93.

19. Wei C.B., Tian X.B., Yang S.Q., Wang X.B., Fu R.K.Y., Chu P.K., Anode Current Effects in Plasma Electrolytic Oxidation, Surface and Coatings Technology, 201 (2007), 5021-5024.

20. Dunleavy C.S., Curran J.A., Clyne T.W., Self-Similar Scaling of Discharge Events through PEO Coatings on Aluminium, Surface and Coatings Technology, 206 (2011), 1051-1061.

21. Curran J.A., Clyne W.T., Thermo-Physical Properties of Plasma Electrolytic Oxide Coatings on Aluminum, Surface and Coatings Technology, 199 (2005), 168-176.

22. Dunleavy C.S., Curran J.A., Clyne T.W., Time Dependent Statistics of Plasma Discharge Parameters during Bulk AC Plasma Electrolytic Oxidation of Aluminum, Applied Surface Science, 268 (2013), 397-409.

23. Dehnavi V., Liu X.Y., Luan B.L., Shoesmith D.W., Rohani S., Phase transformation in plasma electrolytic oxidation coatings on 6061 aluminum alloy, Surface and Coatings Technology, 251 (2014), 106-114.

24. Dehnavi V., Luan B.L., Shoesmith D.W., Liu X.Y., Rohani S., Effect of duty cycle and applied current frequency on plasma electrolytic oxidation (PEO) coating growth behavior, Surface and Coatings Technology, 226 (2013), 100-107.

25. Cheng Y.-1., Xue Z.-G., Wang Q., Wua X.-Q., Matykina E., Skeldon P., Thompson G.E., New findings on properties of plasma electrolytic oxidation coatings from study of an $\mathrm{Al}-\mathrm{Cu}-\mathrm{Li}$ alloy. Electrochimica Acta, 107 (2013), 358-378. 
26. Walsh F.C., Low C.T.J., Wood R.J.K., Stevens K.T., Archer J., Poeton, A.R. and Ryder, A. Review. Plasma Electrolytic Oxidation (PEO) for Production of Anodised Coatings on Lightweight Metal (Al, Mg, Ti) Alloys, Transactions of The Institute of Metal Finishing, 87 (2009), 122-135.

27. Curran J., Plasma Electrolytic Oxidation for Surface Protection of Aluminium, Magnesium and Titanium Alloys, Transactions of The Institute of Metal Finishing, 89 (2011), 295-297.

28. Hussein R.O., Northwood D.O., Nie X., Processing-Microstructure Relationships in the Plasma Electrolytic Oxidation (PEO) Coating of a Magnesium Alloy, Materials Sciences and Applications, 5 (2014), 124-139.

29. Hussein R.O., Nie X., Northwood D.O., The Application of Plasma Electrolytic Oxidation (PEO) to the Production of Corrosion Resistant Coatings on Magnesium Alloys: A Review, Corrosion and Materials, 38 (2013), 55-65.

30. Liang J., Srinivasan P.B., Blawert C., Stormer M., Dietzel W., Electrochemical Corrosion Behaviour of Plasma Electrolytic Oxidation Coatings on AM50 Magnesium Alloy Formed in Silicate and Phosphate Based Electrolytes, Electrochimica Acta, 54 (2009), 3842-3850.

31. Cakmat E., Tekin K.C., Malsyooglu U., Shrestha S., The Effect of Substrate Composition on the Electrochemical and Mechanical Properties of PEO Coatings on Mg alloys, Surface and Coatings Technology, 204 (2010), 1305-1313.

32. Arabal R., Matykina E., Hashimoto T., Skeldon P., Thompson G.E., Characterization of AC Coatings in Magnesium Alloys, Surface and Coatings Technology, 203 (2009), 2207-2220.

33. Wang Y.M., Wang F.H., Xu M.J., Zhao B., Guo L.X., Ouyang J.H., Microstructure and corrosion behavior of coated AZ91 alloy by microarc oxidation for biomedical application, Applied Surface Science, 255 (2009), 9124-9131.

34. Simka W., Sadowski A., Warczak M., Iwaniak A., Dercz G., Michalska J., Maciej A., Modification of titanium oxide layer by calcium and phosphorus, Electrochimica Acta, 56(24) (2011), 8962-8968.

35. Jin F. Y., Tong H. H., Shen L. R., Wang K., Chu P. K., Micro-structural and Dielectric Properties of Porous $\mathrm{TiO}_{2}$ Films Synthesized on Titanium Alloys by Micro-Arc Discharge Oxidization, Materials Chemistry and Physics, 100(1) (2006), 31-33.

36. Chung C.J., Su R.T., Chu H.J., Chen H.T., Tsou H.K., He J.L., Plasma electrolytic oxidation of titanium and improvement in osseointegration. J. Biomed. Mater. Res. B Appl. Biomater, 101(6) (2013), 1023-1030.

37. Kazek-Kęsik A., Krok-Borkowicz M., Jakobik-Kolon A., Pamula E., Simka W., Biofunctionalization of Ti-13Nb-13Zr alloy surface by plasma electrolytic oxidation. Part I, Surface and Coatings Technology, 276 (2015), 59-69.

38. Kazek-Kęsik A., Krok-Borkowicz M., Jakobik-Kolon A., Pamula E., Simka W., Biofunctionalization of Ti-13Nb-13Zr alloy surface by plasma electrolytic oxidation. Part II, Surface and Coatings Technology, 276 (2015), 23-30.

39. Simka W., Nawrat G., Chlode J., Maciej A., Winiarski A., Szade J., Radwanski K., Gazdowicz J., Electropolishing and anodic passivation of Ti6Al7Nb alloy, Przemysł Chemiczny, 90(1) (2011), 84-90.

40. Yerokhin A.L., Nie X., Leyland A., Matthews A. Characterisation of oxide films produced by plasma electrolytic oxidation of a Ti-6Al-4V alloy, Surface and Coatings Technology, 130(2-3) (2000), 195-206.

41. Rokosz K., Hryniewicz T., Dudek Ł., Malorny W., SEM and EDS analysis of Nitinol surfaces treated by Plasma Electrolytic Oxidation, Advances in Materials Science, 15(45) (2015), 41-47. 
42. Rokosz K., Hryniewicz T., Plasma Electrolytic Oxidation as a modern method to form porous coatings enriched in phosphorus and copper on biomaterials, World Scientific News, 35 (2016), 44-61.

43. Rokosz K., Hryniewicz T., Raaen S., Development of plasma electrolytic oxidation for improved Ti6A14V biomaterial surface properties, The International Journal of Advanced Manufacturing Technology, (2015), DOI: 10.1007/s00170-015-8086-y

44. Sowa M., Kazek-Kęsik A., Socha R.P., Dercz G., Michalska J., Simka W., Modification of tantalum surface via plasma electrolytic oxidation in silicate solutions, Electrochimica Acta, 114 (2013), 627-636.

45. Sowa M., Kazek-Kęsik A., Krząkała A., Socha R.P., Dercz G., Michalska J., Simka W., Modification of niobium surfaces using plasma electrolytic oxidation in silicate solutions, Journal of Solid State Electrochemistry, 18(11) (2014), 3129-3142.

46. Simka W., Sowa M., Socha R.P., Maciej A., Michalska J., Anodic oxidation of zirconium in silicate solutions, Electrochimica Acta, 104 (2013), 518-525.

47. Simka W., Habilitation summary of professional accomplishments (in Polish). Silesian University of Technology (Wydział Chemiczny, Politechnika Sląska), Gliwice, Chemical Engineering Department, 2013, 1-18.

48. Jelinek M., Kocourek T., Remsa J., Weiserová M., Jurek K., Mikšovský J., Strnad J., Galandáková A., Ulrichováe J., Antibacterial, cytotoxicity and physical properties of laser-silver doped hydroxyapatite layers, Materials Science and Engineering: C, 33(3) (2013), 1242-1246.

49. Mishra G., Dash B., Pandey S., Mohanty P.P., Antibacterial actions of silver nanoparticles incorporated $\mathrm{Zn}-\mathrm{Al}$ layered double hydroxide and its spinel, Journal of Environmental Chemical Engineering, 1(4) (2013),1124-1130.

50. Rajendran A., Pattanayak D.K., Silver incorporated antibacterial, cell compatible and bioactive titania layer on Ti metal for biomedical applications, RSC Advances, 106(4) (2014), 6144461455.

51. Trujillo N.A., Oldinski R.A., Ma H., Bryers J.D., Williams J.D., Popat K.C., Antibacterial effects of silver-doped hydroxyapatite thin films sputter deposited on titanium, Materials Science and Engineering: C, 32(8) (2012), 2135-2144.

52. Hempel F., Finke B., Zietz C., Bader R., Weltmann K-D., Polak M., Antimicrobial surface modification of titanium substrates by means of plasma immersion ion implantation and deposition of copper, Surface and Coatings Technology, 256 (2014), 52-58.

53. Bellows C.G., Heersche J.N., Aubin J.E., Aluminium accelerates osteoblastic differentiation but is cytotoxic in long-term rat calvaria cell cultures, Calcif. Tissue Int., 65 (1999), 59-65.

54. Krewski D., Yokel R.A., Nieboer E., Borchelt D., Cohen J., Harry J., Kacew S., Lindsay J., Mahfouz A.M., Rondeau V., Human health risk assessment for aluminium, aluminium oxide, and aluminium hydroxide, J. Toxicol. Environ. Health B Crit. Rev., 10(1) (2007),1-269.

55. Solving Titanium Implant Osseointegration Problems by Using Epoxy/Carbon-Fiber-Reinforced Composite, Titanium Today, (2015), 26-28.

56. Browne R.C., Vanadium poisoning from gas turbines, British Journal of Industrial Medicine, 2(12) (1995), 57-59.

57. Jacobs J.J., Skipor A.K., Black J., Urban R., Galante J.O., Release and excretion of metal in patients who have a total hip-replacement component made of titanium-base alloy, The Journal of Bone and Joint Surgery, 73 (1991), 1475-1486. 
58. Aluminum CAS \# 7429-90-5, PUBLIC HEALTH STATEMENT, Agency for Toxic Substances and Disease Registry, Division of Toxicology and Environmental Medicine, http://www.atsdr.cdc.gov, Atlanta GA, 2008.

59. Landsberg J.P., McDonald B., Watt F., Absence of aluminium in neuritic plaque cores in Alzheimer's disease, Nature, 360 (1992), 65-68.

60. Seiler H.G., Sigel H., Sigel A., Handbook of toxicity of inorganic compounds, Marcel Dekker Inc., 1998, New York, NY. 